\title{
PERANAN KOMPETENSI GURU PENDIDIKAN AGAMA ISLAM (PAI) DALAM MENINGKATKAN INTERAKSI PEMBELAJARAN DI SEKOLAH
}

\author{
Hairuddin Cikaa \\ Program Studi Sejarah Peradaban Islam, FUAD, IAIN Palu \\ hairuddincikka@iainpalu.ac.id
}

\begin{abstract}
ABSTRAK
Guru PAI harus memiliki 5 kompetensi yaitu pedagogik, kepribadian, sosial profesional dan kepemimpinan dalam interaksi pembelajaran guru PAI dituntut agar dapat mampu membangun interaksi dengan siswa karena interaksi pembelajaran yaitu aktifitas sosial antara siswa dengan teman sebayanya, siswa dengan gurunya dalam bentuk komunikasi sosial dikelas maupun diluar kelas.
\end{abstract}

Kata Kunci: Kompetensi, Guru, Interaksi Pembelajaran

\section{ABSTRACT}

PAI teachers must have 5 competencies, namely pedagogic, personality, social, professional and leadership in learning interactions. PAI teachers are required to be able to build interactions with students because learning interactions are social activities between students and their peers, students and teachers in the form of social communication in the classroom or outside the classroom.

Keywords: Competence, Teachers, Learning Interactions

\section{PENDAHULUAN}

Seorang pendidik atau guru adalah orang yang paling menentukan perjalanan pendidikan yang wajib mendapatkan perhatian secara terpusat pertama dan paling utama. Sosok seorang guru selalu menjadi sorotan yang sangat strategis jika berbicara tentang problem pendidikan, karena guru memiliki keterikatan penting dalam pendidikan. Guru mempunyai peran besar dalam pembangunan sistem pendidikan dan menentukan sukses atau tidaknya seorang siswa, khususnya dalam proses pembelajaran. Pendidik merupakan pilar yang sangat berpengaruh dalam menciptakan proses pendidikan, serta apa yang akan dicapai sehingga pendidikan menjadi bermutu (Mulyasa, 2007).
Guru harus memiliki kompetensi atau kemampuan yang mutlak harus ada pada dirinya agar dapat menjalankan tugas dan fungsinya secara maksimal. Mulyasa, (2007) mengatakan bahwa guru yaitu seseorang yang memiliki kewenangan dan bertanggung jawab secara penuh dalam penyelenggaraan pendidikan kepada siswa baik secra perorangan maupun klasikal, baik dilingkungan sekolah ataupun diluar. Ini menandakan bahwa guru minimal mempunyai dasar kompetensi atau kemampuan dalam sebagai bentuk hak kewenangan dan kompetensi dalam menjalankan profesinya. Oleh karenanya, kemampuan yang wajib mutlak dimiliki oleh seorang guru adalah keterampilan atau kecakapan, didalam pengelolaan aktifitas 
pembelajaran. Dengan demikian keterampilan guru merupakan kompetensi dalam menjalankan tugas dalam proses pembelajaran.

UU RI No.14 tahun 2005 tentang guru dan dosen pasal 1, ayat 10 , menyebutkan bahwa: Kompetensi adalah seperangkat pengetahuan, keterampilan, dan perilaku yang harus dimiliki ,dihayati dan dikuasai oleh guru atau dosen dalam melaksanakan tugas keprofesionalan."

Kompetensi yaitu penggabungan pengatahuan ataua daya pikir, Perilaku atau daya hati, dan skill/daya fisik yang dihasilkan dalam bentuk perbuatan. Dengan makna lain kompetensi dapat diartikan sebaga peleburan pengetahuan, skill, penilaian dan sikap/perilaku yang diwujudkan dalam pembiasaan pemikiran dan bertindak dalam mewujudan tugas tanggung jawab pekerjaannya.

Kemampuan guru dalam melaksanakan tugas khususnya dalam penguasaan bahan ajar, penyusunan rencana pembelajaran, kompetensi dalam penyusunan perangkat nilai dari hasil belajar anak didik dan pengalaman pendidik dalam mengajar serta cakrawala keilmuan yang luas dalam pendidikan, selain itu guru harus memiliki pemahaman yang sangat dalam terhadap kondisi peserta didik. (Sahertian, 2010). Menurut Djamarah (1994) Gur yang memiliki kompetensi tak hanya dituntut agar mempunyai penguasaan terhadap keilmuannya, penyusunan bahan pengajaran, metodologidalam proses pembejalaran, profesiaolisme guru adalah suatu keharusan didalam menciptakan sekolah berlandaskan pengetahuan, yakni kemampuan memahami tentang belajar-mengajar, kurukilum serta pembentukan gaya belajar siswa. Kemampuan secara profesional (Kompetensi Profesional) dalam hal ini berkaitan era dengan tugas pokok guru dalam mengajar.

Proses interaksi atau hubungan timbal balik pendidik dan anak didik sering disebut dengan istilah interaksi dalam proses pembelajaran. Keterkaitan interaksi merupakan proses komunikasi yang terpenting bagi tiap manusia karena dengan komunikasi maka akan tercipta hubungan emosional serta terwujudnya hubungan yang harmonis. Secara istilah komunikasi berasal dari kata communicare yang memilki makna berperan aktif, menyampaikan, dan menjadi milik secara bersama-sama. Oleh karena itu secara konseptual komunikasi telah mengandung makna memberitahukan kabar tau berita, pengetahuan tentang pikiran, nilainilai dengan tujuan untuk menggugah peran aktif tentang apa yang disampaikan dan menjadi milik secara bersama-sama (Djaali, 2007).

Belajar yaitu pembentukan perilaku dengan melaksanakan berbagai aktifitas baik berupa aspek kognitif, afektif dan psikomotor. Aktiftas dalam belajar bukan hanyafdalam mengingat melainkan juga mersakan secara langsung, karena seseorang disebut belajar apabila ia melakukannya secara kontinyu. Berdasarkan pengertian yang dimaksud Satori berpendapat bahwa dalam belajar harus selalu senantiasa mampu memperbaiki perilaku, penampila dengan rangkaian kegiatan pembelajaran contoh mengamati, membaca, mendengar, menirukan dan lain-lain (Satori, 2003).

Mengajar yaitu proses transver pengetahuan kepada siswa atauanak didik , mengajar harus didasari dengan usaha dalam mewujudkan situasi atau sistem lingkungan yang menjadi pendukung dan memungknkan agar dalam proses belajar terlaksana secara efisien. Selian pengertian diatas mengajar juga diartikan sebagai suatu kegiatan pengorganisasian atau mengatur kawasan pendidikan dengan baik dengan menghubungkannya dengan siswa sehingga terwujud suatu proses pembelajaran.

Dalam aktifitas pengelolaan interaksi dalam pembelajaan guru harus mempunyai 2 modal paling dasar yaitu kompetensi dalam membuat desain program dan memiliki keterampilan dalam mengimplementasi program tersebut kepada anak didik. Dimana didalam pengelolaan aktifitas pembelajaran, aktifitas interaksi guru dan murid adalah kegiatan yang sangat mendominasi. Selanjutnya didalam aktifitas antara pendidik dan anak didik didalam mentransver pengetahuan dan nilai akan selalu dituntut komponen yang seimbang diantara komponen yang satu dan lainnya. 
Melihat peran guru yang sangat urgen guru PAI dituntut agar memiliki penguasaan bidang profesi sesuai latar pendidikannya, khususnya dalam proses pembelajaran guru PAI dituntut bereparan aktif dan kegiatan interaksi pembelajaran. Peran guru PAI dianggap sangat penting dan strategis dalam upaya mewujudkan keberhasilan proses pembelajaran ini akan terwujud apablaguru mampu dan mau memposisikan dirinya sebagai pegawai yang bekerja profesional bukan karena hanya tuntutan tugas mengajar. Dengan demikian, guru akan disanjung, diagungkan dan dikagumi, karena perannya yang sangat penting diarahkan ke arah yang dinamis yaitu menjadi pola relasi antara guru dan lingkungannya, terutama anak didiknya.

Dalam mewujudkan campaian isntruksional setiap komponen saling memberikan respon dan mempengaruhis satu sama lain. Sehingga seorang guru dalam pengelolaan interaksi dalam pembelajaran dapat mendesaian dari setiap komponen yang aka mewujdkan proses belajar mengajar yang optimal. Oleh sebab itu guru dalam mengembangkan interaksi pembelajaran harus lebih dinamis yang bertujuan apayang diharapkan dari capaian atau tujuan instruksional terwujud sesuai harapan.

Guru memiliki kewajiban menyampaikan pengetahuan kepada para siswa sementara para siswa yaitu sekelompok orang yang menerimah pengarus dari guru yang menjalankan aktifitas pembelajaran. Antara pendidik dan anak didik adalah unsur vital dalam aktifitas pembelajaran, karena semua proses, kegiata orentasi serta relasi yang lainnya tercipta untuk melaksanakan penyelenggaraan pendidikan yan selalu melibatkan keberadaan guru dan siswa sebagai aktor pelaksana pendidikan. Dan hal tersebut telah menjadi persyaratan wajib atas penyelenggaraan aktifitas pendidikan.

Pendidikan yaitu uaoata secara sadar seorang guru yang memiliki tujuan dalam pengembangan mutu anak didik. Termuat sebuah arti atau makana bahwa proses yang dilabeli nama pendidikan tersebut tak akan pernah terlaksana jika tidak unsur pelaksana dan melaksankan proses pembelajaran yaitu guru dan anak didik sehiangga dapat disebut bahwa guru dan anak didik adalah pilar pokok dalam proses pendidikan.
Menurut Sagala (2009) pembelajaran yaitu proses interaktif yang memiliki nilai normatif yang bermakna pada prose kegiatannya anak didik berorentasi pada pegangan yang memiliki ukuran, norma dan nilai yang ia yakini. Setiap proses interaksi pembelajaran pasti memiliki tuuan, dan tujuan inilah yang menjadi penentu cara dan model interaksi. Dalam mengajar terwujud suatu prose dalam menguji strategi dan perencanaan yang memungkinkan munculnya perilaku belajar pada anak didik.

Demi menunjang keseksesan dalam proses pembelajaran tiap guru harus selalu mengasah peningkatan kompetensinya, baik dalam keikutsertaannya dalam berbagai kagiatan yang akan meningkatkan kompetensinya seperti untuk menunjang keberhasilan dalam proses pembelajaran setiap guru harus meningkatkan kemampuanya, baik melalui keikutsertaannya dalam berbagai pelatihan, seminar, lokakarya, maupun melakukan studi penelitian kependidikan seperti penelitian tindakan kelas (PTK). Dengan berbagai kegiatan tersebut guru akan memiliki kemampuan dalam mengembangkan kepakarannya dalam mengajar yang meliputi strategi dan teknik mengajar, pengelolaan kelas, peningkatan kedisiplinan dikelas dan pengimplementasian prinsip belajar-mengjar (Suyanto dan Jihad, 2013).

Oleh karenannya dalam proses tersebut guru harus memiliki konsep dan cara dalam pembelajaran yang ia akan terapkan dalam proses pembelajaran di kelas kepada anak didiknya. Agar anak didik mempunyai keinginan yang mumpuni dalam belajar (minat belajar) terhadap setiap pelajaran yang telah disampaikn oleh gurunya, anak didik akan menjadi malas dan belajar jika urunya kurang optimal dan maksimal dalam memberikan pembelajaran dikelas karena yang salah satuyang menentikan berjalan atau tidaknya proses belajar dikelas adalah minat belajar.

Proses belajar dikelas dan hasil yang didapatkan oleh anak didika bukan hanya ditentukan lewat sekolah, bentuk, organisasi (struktur), dan isi dari kurikulum melankan paling besar ditentukan oleh kemampuan guru dalam medidik, mengajar dan memotivasi anaka didiknya dikelas. Guru 


\section{Hairuddin Cikka}

adalah aktor utama dalam memotivasi anak didiknya untuk itulah kompetensinya harus betul berkompeten membuat lingkungan belajar yang efektif, menyenangkan serta pengelolaan kelasnya. Sehingga dalam proses pembelajaran anak didik termotivasi dan mitovasi belajar mereka semakin meningkat.

Peranan seorang guru dalam proses pendidikan yaitu menjadi subjek dalam aktifitas pembelajaran di sekolah,secara lansung guru berbaur dengan anak didiknya dan memegang peran yang sangat vital dan penting dalam semua aktifitas pembelajaran demi terwujudnya tujuan pendidikan. Dalam Hal ini Guru PAI harus mampu memainkan peran karena pelajaran agam adalah pelajaran yang membentuk akhlak dan peketi anak didik hal ini terbukti jika pelajaran agama berlangsung anak didik sangat antusias dalam mengikutinya karena dasar yang telah ditanamkan orang tuanyadari rumah khususnya pendidikan agama telah ada dan tugas guru tinggal mengembangkan apa yang telah ada. Dengan cara mengaitkan materi dengan proses kehidupan nyata yang disertai dengan contoh kongkrit.

Dalam konteks tersebut inilah seorang guru PAI dalam proses pemebelajaran dtuntut dapat melakukan penumbuhan dan peningkatan minat pada setiap subjek yang baru dengan mencotoh minat-minat yang telah ia liahat dalam proses pembelajaran dengan itu ia akan melakukan inovasi-inovasi baru dalam pembelajaran. Dimana didalam proses pembelajaran seorang guru PAI lebih dahulu menyiapkan perangkat pembelajaran yaitu berupa rencana pengajaran, menyusun persiapan pembelajaran, menggunakan media pembelajaran serta dalam memberikan materi pelajaran sudah sesuai dengan tujuan yang ada dalam kurikulum. Hal tersebut bertujuan untuk menjadi pegangan guru dalam melakukan proses pembelajaran yang terarah, fektif dan efisien. Pembelajaran yang mengarah pada pembelajaran aktif yang mengacu pada keselarasan antara tujuan, materi dan alat penilai.

Dalam proses pembelajaran guru PAI harus selalu menanamkan hubungan yang erat dengan anak didiknya sebagai wadah agar mempermudah dalam berkomunikasi, antara guru dan anak didiknya dengan selalu bersikap lemah lembut, bijal serta menjadi contoh atau teladan yang baik (uswatun hasanah). Seorang guru PAI harus juga dituntut agar mampu menggunakan media pembelajaran dengan maksimal yang ada tersedia disekolah contoh memanfaatkan buku pendidikan yang ada, serta melakukan kegatan praktek di laboratorium sekolah atau dimasjid atau sarana dan prasrana lainnya yang mendukung lancarnya proses pembelajaran.

Seorang guru PAI juga harus senantiasa menerakan kedisiplinan terhadap anak didiknya karena kedisiplinan itu sangat penting dilaksanakan pada peserta didik agar dalam proses pembelajaran terlaksana dengan aman tertib dan lancar, anak didik dapat menerima pelajaran dengan baik dan guru bisa menyampaikan materi pelajaran dengan lancar.

Disamping kedisiplinan, seorang guru harus menjadi pengamat dengan selalu memperhatikan tumbuh kembang anak didiknyaatau perkembangan kemampuan anak didik dengan cara membimbing mereka yang memiliki karakter berbeda beda dalam menyerap materi dalam setiap pelajaran yang diberikan oleh guru.

Selain bertugas memberikan pembimbingan seorang guru juga harus selalu memberikan tugas belajar kepada anak didiknya yaitu pekerjaan rumah (PR) dan memeriksa tugas tersebut, memberikan penilaian yang sesuai denganhasil kerja anak didik serta mengevaluasi apa yang telah dikerkajakan oleh anak didiknya.Penilaian digunakan dengan maksud untuk mengetahui sifat-sifat pencapaian tujuan, baik dari pihak peserta didik maupun dari pihak guru.

Dengan hal tersebut guru yang mempunyai kompetensi dan paham terhadap apa yang baik dalam proses pembelajaran khususnya perencanaan pembelajaran, kompetensi dalam mengajar, pengajaran dengan materi yang sesuai bidangnya, mengajarkan materi pelajaran sesuai dengan kurikulum dan paham akan karakter peserta didik, selalu melakukan pembimbingan dan pengamatan terhadap anak didiknya serta selalu mengevaluasi denngan memakai cara pengajaran yang pas dan cocok, menggunakan media pembelajaran yang 
sesuai perkembangan zaman dan menyesuaikan dengan kemapuan anak didik, penerapan disipli didalan dan diluar kelas, dan turut membantu dalam kelancaran proses administasi pendidikan itulah guru yang akan sukses dalam mengajar. Maka guru tersebut dapat menjalankan tugas secara efektif dan efisien, mereka tidak hanya memerankan fungsi sebagai subjek yang mentransfer pengetahuan kepada peserta didik, melainkan juga melakukan tugas-tugas sebagai fasilitator, motivator dan administrator dalam proses pembelajaran

Berbagai hal tersebut dilaksanakan oleh guru disekolah sehingga apa yang ingin dicapai dari sesuai target dari apa yang diharapakan akan tercapai dengan mudah. Hal tersebut telah sesuai dengan terget tujuan pendidikan secara nasional yakni untuk pengembangan kompetensi dan memciptakan watak serta peradaban suatu bangsa yang bermartabat yang bertujuan mencerdaskan anak bangsa dan pengembangan potensi atau bakat anak didik untuk menjadi manusia yang berimtaq kepada tuhan yang maha esa, memiliki ahlakaul karimah, sehat, berilmu, memiliki kecakapan, kreatifitas, kemandirian dan menjadi warga negara demokratis serta bertanggungjawab.

\section{PEMBAHASAN}

\section{A. Kompetensi Guru}

Pada intinya seorang guru yang profesional harus mempunyai kemampuan didalam melaksanakan tugasnya menjadi orang yang pandai daam mendidik dan mengajar. Guru yang profesional adalah pendidik yang memiliki kecakapan dan kemampuan dalam melakukan tugas pendidikan dan pengajaran. Kompetensi berasal dari kata competency, yang berarti kemampuan atau kecakapan. Menurut kamus bahasa Indonesia, kompetensi dapat diartikan (kewenangan) kekuasaan untuk menentukan atau memutuskan suatu hal (Depdikbud, 1990). Istilah kompetensi sebenarnya memiliki banyak makna yang diantaranya adalah sebagai berikut:

Menurut Usman (2005), kompetensi yaitu sesuatu yang mencerminkan daya dan upaya seseorang baik secara kualitatif dan kuantitatif. Kunandar (2007), berpendapat bahwa kompetensi adalah sikap atau perilaku yang merupakan perilaku yang logis guna mewujudkan sesuatu yang ingin digapai yang dipersyaratkan sesuai dengan kondisi yang diharapkan.

Kompetensi atau kemampuan adalah tugas yang layak yang cukup memadai atas kepemilikan terhadap pengetahuan, skill, dan daya upaya yang menuntut setiap orang dan atau jabatan yang dimilikinya. (Roestiyah, 1989). Kompetensi juga berarti sebagai pengetahuan, keterampilan dan nilai/value paling mendasar yang diwujudkan dalam pembiasaan berpikir dan bertindak (Kunandar, 2007).

Arti kompetensi jika disatukan dengan salah satu profesi misalnya seorang tenaga pendidik atauguru, maka dapat dimaknai bahwa kompetensi seorang guru berarti guru wajib mewujudkan tugasnya sebagai seorang guru dengan selalu meningkatkan kapasitas keilmuannya. Atau dalam makna yang lain kompetensi guru yaitu kemampuan yang wajin dan melekat pada diri seorang pendidik untuk menghasilkan profesionalitas kerja yang tepat, efektif dan efisien (Usman, 2005).

Akan tetapi, andai kata makna kompetensi guru ini terkait dengan Pendidikan Agama Islam (PAI) yakni merupakan pendidikan yang pokok bagi setiap manusia, khususnya dalam menggapai ketenangan batin dan kesehatan mental pada umumnya. Agama merupakan jalan dalam membimbin hidup menuju kehidupan yang terbaik, mencegah manusia agar terhindar dari perbuatan tercela dan menjadi pijakan yang mampu mengendalikan moral setiap manusia. Dapat dikatakan bahwa kompetensi guru PAI yaitu wewenang seorang guru dalam menentukan pembejalajaran PAI yang diajarkannya pada setiap jenjang pendidikan baik di SD, SMP, maupun SMA ditempat guru tersebut mengabdi (Daradjat, 1995).

Diantara para guru khususnya guru PAI sangat berbeda dengan guru yang lainnya. Guru PAI selain Guru agama berbeda dengan guru guru bidang studi lainnya. Guru agama di samping melakukan kewaibannya sebagai guru agama, yaitu mengajar serta membimbing serta membina masalah 
keagamaan kepada anak didiknya guru PAI juga turut serta membentuk karakter kepribadian serta pembinaan ahlakkul karimah anak didiknya (Daradjat, 1995). Kompetensi guru PAI tak hanya unggul dalam kepribadiannya yang dijiwai oleh keutamaan hidup dan nilai-nilai luhur yang dihayati serta diamalkan. Akan tetapi seorang guru PAI hendaknya memiliki kemampuan pedagogis atau hat hal mengenai tugas- tugas kependidikan seorang guru agama tersebut.

Macam-macam Kompetensi Guru sebagai berikut:

\section{Kompetensi Pedagogik}

Yang dimaksud dengan Kompetensi pedagogik yaitu skill atau kompetensi yang dimiliki oleh setiap guru dalam melihat kepribadian atau karakter anak didiknya dari berbagai macam aspek dalam kehidupan, baik moral, emosional, maupun intelektualnya. Pelaksanaan dari kompetensi ini kiranya dilihat dari bagaimana kompetensi seorang guru dalam penguasaannya terhadap prinsip pembelajaran, yang diawali dari teori belajarnya sampai dimana seorang guru harus menguasai bahan ajar (Djam'an, Dkk, 2003).

\section{Kompetensi Kepribadian.}

Inti sikap seorang guru adalah dinilai dari kepribadiannya. Karena dengan kepribadian itulah yang akan menjadi penentu apakah guru tersebut akan menjadi yang mendidik atau membina yang baik terhadap anak didiknya atau sebaliknya guru tersebut menjadi yang merusak atau menghancurkan masa depan anak didiknya khususnya anak didik yang masih usia dibawah pada tingkatan Sekolah Dasar dan mereka yang sedang mengalami kegoncangan jiwa (tingkat menengah) (Djam'an, Dkk, 2003).

Peraturan Pemerintah nomor 19 tahun 2005 tentang Standar Nasional Pendidikan, pasal 28 ayat (3) butir b dikemukakan bahwa kompetensi kepribadian adalah kemampuan yang mencerminkan kepribadian yang mantap, stabil, dewasa, arif dan berwibawa, serta menjadi teladan bagi peserta didik dan berakhlak mulia.

Kompetensi kepribadian yang harus dimiliki oleh seorang guru adalah Kepribadian yang mantap dan stabil,
Kepribadian yang dewasa, Kepribadian yang arif, Kepribadian yang berwibawa serta berakhlak mulia dan teladan bagi peserta didik (Anwar, 2002).

Oleh sebab itu seorag guru wajib memperlihatkan pribadi yang baik terhadap anak didiknya, tidak hanya menggugurkan kewajibannya dalam mengajar disekolah melainkan diluar sekolah juga guru tetap memperlihatkan pribadi yang baik menjadi panutan anak didiknya karna halinilah yang akan menjaga wibawa dan citra guru sebagai seorang yang mendidik, yang akan selalu diikuti oleh anak didik pada khususnya dam masyarakat pada umumnya.

\section{Kompetensi Sosial}

Kompetensi sosial yaitu kompetensi yang wajib dimiliki oleh setiap pendidik dalam berkomunkasi dan bergaul dengan anak didiknya, sesama guru, dan pegaawai lainnya yang ada dilingkungan pendidikan serta wali murid dan masyarakat. Hal ini digambarkan dalam bentuk uraian dalam RPP mengenai pendidik bahwa kompetensi sosial adalah kemampuan seorang pendidik yang menjadi bagian dari masyarakat dalam hal ini seorang pendidik harus memilii kemampuan dalam mengkomunikasikan sesuatu baik secara lisan, tulisan dan dalam bentuk isyarat dan memanfaatkna teknologi informasi dan komunikasi secara fungsional dan bersahabat/bergaul dengan peserta didik, sesama pendidik, tenaga kependidikan, orang tua/wali peserta didik, Bergaul secara santun dengan masyarakat (Sarimaya, 2008).

Dalam hal ini ddapat penulis menyimpulkn bahwa dalam kompetensi sosial seorang pendidik harus mampu menyesuaikan diri dengan bergaul bersama secara selektif denfan membangun interaksi sosial satu dengan lainnya khusunya peserta didik, mampu bergaul secara efektif dengan pendidik dan tenaga kependidikan, serta mampu berkomunikasi secara efektif dengan orang tua/wali peserta didik dan masyarakat sekitarnya.

\section{Kompetensi Profesional}

Guru adalah faktor terpenting dalam penyelanggaraan pendidikan di sekolah. Meningkatkan mutu pendidik tidak hanya dengan menambah nilai kesejahteraan guru dalam bentuk menaikkan gajidan memberi tunjanga khusus melainkan yang paling 
pokok adalah profesionalitasnya. UU No. 14 Tahun 2005 pasal 1 ayat 1: "Menyatakan guru adalah pendidik profesional dengan tugas utama mendidik, mengajar, membimbing, mengarahkan, melatih, menilai, dan mengevaluasi peserta didik pada pendidikan anak usia dini jalur pendidikan formal, pendidikan dasar, dan pendidikan menengah. Sebagai seorang pendidik profesional guru wajib mempunyai potensi pendidik yang cukup dan mumpuni. Kemampuan atau nilai kompetensi seorang pendidik terlihat pada tahap bagaimana guru mampu menerapkan sejumlah konsep, asas kerja sebagai guru, mampu mendemonstrasikan sejumlah strategi maupun pendekatan pengajaran yang menarik dan interaktif, disiplin, jujur, dan konsisten."

Profesi yaitu kedudukan dalam suatu pekerjaan yang mana menuntut keahlian setiap individu, yang mana pekerjaan tersebut takdapat dilaksanakan oleh sembarang orang yang tak memiliki keahlian dibidangnya dan tidak ada persiapan khusus untuk melaksankan pekerjaan yang dimaksud untuk itu tiap orang harus ahli sesuai dengan bidangnya agar dapat disebut profesional dalam bekerja. Kompetensi profesional berkaitan dengan bidang yaitu Memahami mata pelajaran yang telah dipersiapkan untuk mengajar, Memahami standar kompetensi dan standar isi mata pelajaran yang tertera dalam Peraturan Pemerintah serta bahan ajar yang ada dalam kurikulum tingkat satuan pendidikan (KTSP), Memahami struktur, konsep, dan metode keilmuan yang menaungi materi ajar, Memahami hubungan konsep antar mata pelajaran terkait, Menerapkan konsep-konsep keilmuan dalam kehidupan sehari-hari (Sudjana, 2009).

\section{Kompetensi Kepemimpinan}

Kompetensi kepemimpinan yaitu kompetensi guru dalam menjalankan tanggung jawabnya terhadap profesinya sebagai pendidik, yang mana dalam hal ini guru harus mampu merencanakan,membudayakan, dan mengamalkan pembelajaran agama dan sikap ahlak yang mulia pada lingkungan pendidikan atau sekolah sebagai salah satu bagian dari proses pembelajaran agama, kemampuan dalam mengelola potensiyang ada dilingkungan sekolah yang secara sistematis dalam menyokong pembudayaan dalam pengamalan agama pada komunitas atau kelompok dilingkungan pendidikan. kemampuan menjadi inovator, motivator, fasilitator, pembimbing dan konselor dalam pembudayaan pengamalan ajaran agama pada komunitas sekolah, dan Kemampuan menjaga, mengendalikan dan mengarahkan pembudayaan pengamalan ajaran agama pada komunitas sekolah dan menjaga keharmonisan hubungan antar pemeluk agama dalam bingkai Negara Kesatuan Republik Indonesia (NKRI). Guru profesional tercermin dalam tanggung jawabnya sebagai guru kepada peserta didik, orang tua, masyarakat, bangsa, negara dan agamanya (PMA, 2010).

\section{B. Interaksi Pembelajaran. \\ 1. Pengertian Interaksi Pembelajaran.}

Interaksi terdiri dari kata inter (antar), dan aksi (kegiatan (Idris, 1987). Jadi interaksi adalah kegiatan timbal balik. Dari segi terminologi "interaksi" mempunyai arti hal saling melakukan aksi; berhubungan; mempengaruhi; antar hubungan (Depdikbud, 1990). Interaksi memiliki hubungan yang sangat erat dengan istilah komunikasi sedangkan komunikasi bertumpu pada perkataan "communicare" yang berperan aktif, menyampaikan, menjadi milik bersama Sardiman AM (2001), mengatakan didalam berkomunikasi ada beberapa hal yang terkait yaitu unsur yang ada dalam proses komunikasi tersebut yaitu komunikan dan komunikator. Keterkaitan antara keduanyaa biasanya menginteraksikan sesuatu, yang kita kenal dengan istilah pesan dalam dalam penyamaian pesan tersebut dibutuhkan media atau alat. Jadi, di dalam komunikasi terdapat empat unsur yaitu: komunikan, komunikator, pesan, dan saluran atau media.

Interaksi dalam pembelajaran yaitu aktifitas yang terjadi secara timbal balik antara pendidik dan anak didiknya yang dapat kita istilahkan sebagai suatu aktifitas secara sosial karena ada peserta didik dan sahabatnya serta anatar peserta didik dengan pendidiknya ada suatu interaksi yang terbangun yaitu komunikasi sosial atau pergaulan (Idris, 1987). Sedangkan menurut Soetomo (1993), bahwa interaksi pembelajaran ialah ikatan erat diantara 


\section{Hairuddin Cikka}

pendididk dan peserta didik yang memperlihatkan adanya ikatan yang sifatnya edukatif (mendidik) (Idris, 1987). Dalam hal ini interaksi mengarah pada satu cit-cita atau harapan tertentu yang sifatnya mendidik, yakni dengan adanya trnasformasi perilaku anak didik ke arah kedewasaan.

Berdasarkan beberapa penjelasan diatas dapat disimpulkan bahwa interksi dalam pembelajaran adalah hubungan erat atau timbal balik yang terbangun antara pendidik dan anak didiknya dalam mencapai tujuan pembelajaran.

\section{Pola Komunikasi dalam Interaksi Pembelajaran}

Menurut Sudjana, terdapat 3 bentuk pola dalam proses interaksi antara pendidik dan anak didiknya yaitu komunikasi sebagai aksi, interaksi dan transaksi.

a. Komunikasi sebagai aksi atau komunikasi satu arah

Dalam hal ini pendidik sebagai pemberi aksi dan anak didik penerima dari aksi tersebut. Pendidik atau guru yang sangat berperan aktif sedangkan anak didiknya pasif, dan mengajar hanya dianggap sebagai aktifitas penyampaian bahan ajar.

b. Komunikasi sebagai interaksi atau komunikasi dua arah

Yaitu pendidik atau guru sebagai pelaku dalammeberikan aksi dan penerima aksi sedangkan anak didik bisa juga sebagai orang yang menerima an memberi aksi. Dan dalam kegiatan ini akan terjalin interaksi komunikasi antara pendidik dan anak didiknya.

c. Komunikasi sebagai transaksi atau komunikasi banyak arah

Yaitu interaksi komunikasi yang terbangun tidak hanya melibatkan pendidik dan anak didik melainkan diantara sesama anak didik. Anak didik dalam hal ini harus lebih aktif dari pendidik. Anak didik seperti halnya pendidik dapat berguna sebagai sumber belajar bagi anak didik yang lainnya (Sudjana, 1989).

Kondisi dalam pemberian pengajaran kepada anak didik atu dimana proses interaksi dalam pembelajaran terbangun sebagaimana pola komunikasi menurut Sudjana dapat dikatan sebagai tarnsaksi suatu konsep yang sesuai dengan cara belajar siswa aktif (CBSA). Sebagaimana yang yang diinginkan oleh para pakar dalam pendidikan masa kini (modern). Menurut Sudjana (1989), ada empat interaksi pendidikan yaitu: interaksi peserta didik dengan peserta didik, interaksi peserta didik dengan guru, Interaksi peserta didik dengan sumber belajar, dan Interaksi peserta didik dengan lingkungan (Sudjana, 1989).

Pola komunikasi yang terbangun dengan adanya interaksi pendidik dan anak didik di kels menciptakan anak didik yang aktif dalam pembelajaran (arus komunikasi). Menurut Heinich dalam Sudjana, (1989) terdapat empat macam pola dalam arus komunikasi yaitu komunikasi gurupeserta didik searah, komunikasi dua arah arus bolak-balik, komunikasi dua arah antara guru-peserta didik dan peserta didik-peserta didik dan komunikasi optimal total arah. Dalam proses interaksi antara guru dan peserta didik memiliki pola yang meliputi sebagai berikut:

a. Pola dasar interaksi

Yang sangat mendominasi dalam pola dasar interaksi yaitu guru lebih dominan dari anak didiknya atau bahkan anak didik juga yang dominan karena unsur pola dasar dalam interaksi yang terbangun belum terlihat yang meliputi unsur guru, isi pembelajaran dan peserta didik yang semuanya belum ada yang mendominasi proses interaksi dalam pembelajaran. Dijelaskan bahwa adakalanya guru mendominasi proses interaksi, adakalanya isi yang lebih mendominasi, adakalanya juga peserta didik yang mendominasi interaksi tersebut atau bahkan adakalanya antara guru dan peserta didiknya secara seimbang saling mendominasi.

b. Pola interaksi berpusat pada isi

Pada tahap ini proses pembelajaran aktifitas pendidik lebih megajarkan pada isi pelajaran disatu sisi dan anak didik belajar dari isi tersebut dengan bentuk yang berbeda akan tetapi aktifitas masih berpusat pada isi/materi pembelajaran.

c. Pola interaksi berpusat pada guru

Selanjutnya pada tahap ini pembelajaran yang berlangsung hanya berpusat pada pendidik atau guru, yang pada umumnya penguaraian pembelajaran yang bersifat menguraikan pembelajaran yang terpusat baik dalam pengurian isi atau materi ajar. Dalam pengimplementasian 
pembelajaran in, aktifitas secara total ada ditangan pendidik, sedangkan anak didik hanya sebagai penerima dan diberi pembelajaran yang diistilahkan anak didik yang pasif.

d. Pola interaksi berpusat pada peserta didik

Pada tahap ini aktifitas pembelajaran berpusat pada anak didik. Anak didik melakukan sendiri perencanaan terhadap materi pembelajaran apa yang ia pelajari, dan melakukan tahap proses belajar dalam materi ajaryang telah diberikan oleh gurunya sendiri. Peran guru lebih bersifat permisif, yaitu mengizinkan tiap aktifitas yang dilaksanakan oleh anak didik dalam belajar terhadap apapun yang diinginkannya. Dalam menambahkan keaktifan dalam aktifitas pembelajaran ini pendidik harus menciptakan perancanaan yang matang dengan baik, dan dalam mengimplementasikan pelaksanaannya didasai atas planing yang telah direncanakan. Dengan demikian dapat diharaapkan hasil yang maksimal dari anak didik sehingga terjadi keseimbangan keaktifan baik dipihak guru maupun dipihak peserta didik (Hidayatul, Interaksi Belajar Mengajar dalam

http://musliemforefer.wordpress.com).

Oleh sebab itu Pada proses pembelajaran efektivitas, interaksi antara guru dan peserta didik menjadi hal yang sangat penting agar proses belajar mengajar yang disampaikan oleh guru dapat diterima, dipahami dan dicerna dengan baik oleh peserta didik. Selain itu pula terjalinnya interaksi yang baik antara peserta didik dan guru maka akan dapat memberikan kenyamanan, rasa tenang, dan motivasi yang tinggi, bagi peserta didik maupun guru dalam proses belajar mengajar sehingga dapat meningkatkan prestasi belajar pada peserta didik.

\section{KESIMPULAN}

Kompetensi Guru PAI: (1) Pedagogik, yaitu skill atau kompetensi yang dimiliki oleh setiap guru dalam melihat kepribadian atau karakter anak didiknya dari berbagai macam aspek dalam kehidupan, baik moral, emosional, maupun intelektualnya, (2) Kepribadian, Inti sikap seorang guru adalah dinilai dari kepribadiannya. Karena dengan kepribadian itulah yang akan menjadi penentu apakah guru tersebut akan menjadi yang mendidik atau membina yang baik terhadap anak didiknya atau sebaliknya guru tersebut menjadi yang merusak atau menghancurkan masa depan anak didiknya khususnya anak didik yang masih usia dibawah pada tingkatan Sekolah Dasar dan mereka yang sedang mengalami kegoncangan jiwa (tingkat menengah), (3) Sosial yaitu kompetensi yang wajib dimiliki oleh setiap pendidik dalam berkomunkasi dan bergaul dengan anak didiknya, sesama guru, dan pegaawai lainnya yang ada dilingkungan pendidikan serta wali murid dan masyarakat (4) Profesional, mengikutkan guru dalam pelatihan, KKG, seminar, diklat dan juga studi banding ke lembaga lain dalam rangka meningkatkan prestasi dan wawasan dan supervisi dilakukan dengan tujuan untuk mengembangkan kemampuan dalam proses pembelajaran, (5) Kepemimpinan, kemampuan seorang guru untuk mempengaruhi peserta didik yang di dalamnya berisi serangkaian tindakan atau perilaku tertentu terhadap peserta didik menggunakan pendekatan personal, nasihat, sangsi untuk membentuk kepribadian yang baik kepada peserta didik

Interaksi dalam pembelajaran yaitu aktifitas yang terjadi secara timbal balik antara pendidik dan anak didiknya yang dapat kita istilahkan sebagai suatu aktifitas secara sosial karena ada peserta didik dan sahabatnya serta anatar peserta didik dengan pendidiknya ada suatu interaksi yang terbangun yaitu komunikasi sosial atau pergaulan adapun contohnya yaitu, Interaksi guru terhadap peserta didik dengan cara, pengaturan kelas, menjelaskan materi pelajaran, mengajukan pertanyaan pada peserta didik, pemberian point/ nilai, pemberian latihan soal pada peserta didik, memeriksa hasil kerja peserta didik, pengulangan materi pelajaran, pemberian tugas belajar, pemberian tugas diskusi. Kedua, Interaksi peserta didik terhadap guru, menjawab pertanyaan guru, mengerjakan soal, mengerjakan tugas diskusi, mencatat pelajaran, mengulangi materi pelajaran, mengerjakan tugas di depan. 


\section{Hairuddin Cikka}

\section{DAFTAR PUSTAKA}

A.M., Sardiman. (2001). Interaksi dan Motivasi Belajar Mengajar. Jakarta: Raja Grafindo Persada.

Anwar, Qomari. (2002). Reorientasi Pendidikan Dan Profesi Keguruan. Jakarta : Uhamka Press.

Daradjat, Zakiyah. (1995). Pendidikan Islam Dalam Keluarga dan Sekolah. Jakarta: Ruhama.

Departemen Pendidikan dan Kebudayaan. (1990). (Tim Penyusun Kamus Pusat Pembinaan dan Pengembangan Bahasa), Kamus Besar Bahasa Indonesia. Jakarta: Balai Pustaka.

Djaali. (2007) Psikologi pendidikan. Jakarta: Bumi Aksara.

Djam'an Satori, dkk. (2003). Materi Pokok Profesi Kependidikan. Jakarta: Universitas Terbuka.

Djamarah, Syaiful Bakhri. (1994). Prestasi Belajar dan Kompetensi Guru. Surabaya: Usaha Nasional.

Idris, Zahara. (1987). Dasar-dasar Kependidikan. Padang: Angkasa Raya.

Khafidoh, Uci Hidayatul. Interaksi Belajar Mengajar"'http://musliemforefer.word press.com Diakses, 20 Maret 2020.

Mulyasa, E. (2007). Standar Kompetens Dan Sertifikasi Guru. Bandung: PT. Remaja Rosdakarya.

N.K, Roestiyah. (1989). Masalah-masalah Ilmu Keguruan . Jakarta: Bina Aksasa.

Peraturan Menteri Agama Republik Indonesia Nomor 16 Tahun 2010 pasal 16.

Sagala, Syaiful. (2009). Kemampuan Profesional Guru dan Tenaga Kependidikan. Bandung: Alfabeta.

Sarimaya, Farida. (2008). Sertifikasi Guru. Bandung:Yrama Widya.

Suhertian, Piet. (2010. )Profil Pendidik Profesional. Jakarta: Andi Offset.

Suyanto dan Jihad, Asep. (2013). Menjadi Guru Profesional: Startegi Meningkatkan Kualifikasi dan Kualitas Guru Di Era Global. Jakarta: Erlangga.
Soetomo. (1993). Dasar-dasar Interaksi Belajar Mengajar. Surabaya: Usaha Nasional.

Usman, Moch Uzer. (2007). Menjadi Guru Profesional. Bandung: PT. Remaja Rosdakarya.

UU RI No.14 tahun 2005 tentang Guru dan Dosen. 